\title{
Interleukin 12 at the Site of Disease in Tuberculosis
}

\author{
Ming Zhang, ${ }^{*}$ Maurice K. Gately, ${ }^{*}$ Erica Wang, ${ }^{*}$ Jianhua Gong, ${ }^{\star}$ Stanley F. Wolf, ${ }^{3}$ \\ Shuzhuang Lu, * Robert L. Modlin," and Peter F. Barnes * \\ ${ }^{*}$ Department of Medicine, University of Southern California School of Medicine, Los Angeles, California $90033 ;{ }^{\ddagger}$ Hoffmann-La Roche, \\ Inc., Nutley, New Jersey 07110; §Genetics Institute, Cambridge, Massachusetts 02140; and "Division of Dermatology and Department \\ of Microbiology and Immunology, UCLA School of Medicine, Los Angeles, California 90024
}

\begin{abstract}
Interleukin 12 (IL-12), a heterodimeric cytokine composed of p40 and p35 chains, has potent immunologic effects in vitro. We used tuberculous pleuritis as a model to study the immunoregulatory potential of IL-12 in vivo at the site of human infectious disease. Messenger RNAs for p40 and p35 were detected in pleural fluid from six of six patients by reverse-transcription polymerase chain reaction. By using an ELISA that detected both free p40 and heterodimeric IL-12, we found that mean concentrations were $585 \pm 89 \mathrm{pg} / \mathrm{ml}$ in pleural fluid of patients with tuberculous pleuritis, which were significantly higher than those in serum of the same patients $(54 \pm 36 \mathrm{pg} /$ $\mathrm{ml}$ ), or in malignant pleural effusions $(123 \pm 35 \mathrm{pg} / \mathrm{ml})$. By using an ELISA specific for heterodimeric IL-12, we found that mean concentrations in pleural fluid of patients with tuberculous pleuritis were $165 \pm 28 \mathrm{pg} / \mathrm{ml}$ and undetectable in serum of the same patients, or in malignant pleural effusions. Bioactive IL-12 was detectable in five of five supernatants of pleural fluid cells stimulated with Mycobacterium tuberculosis. Addition of anti-IL-12 antibodies suppressed proliferative responses of pleural fluid cells to $M$. tuberculosis by $36 \pm 7 \%$. These data indicate that IL-12 may play a role in the human immune response to infectious agents in vivo. We hypothesize that IL-12 contributes to the antimycobacterial immune response by enhancing production of interferon- $\gamma$, facilitating development of Th1 cells and augmenting cytotoxicity of antigen-specific $T$ cells and natural killer cells. (J. Clin. Invest. 1994. 93:17331739.) Key words: cytokine $\bullet$ cytotoxicity $\bullet$ pleuritis $\bullet T$ lymphocyte • Th1 cells
\end{abstract}

\section{Introduction}

IL-12, originally identified as natural killer $(\mathrm{NK})^{1}$ cell stimulatory factor and cytotoxic lymphocyte maturation factor, is a disulfide-linked heterodimeric cytokine composed of two subunits of molecular masses of $40 \mathrm{kD}(\mathrm{p} 40)$ and $35 \mathrm{kD}$ (p35) (1-4). Among the plethora of cytokines produced by mononuclear cells, IL-12 has distinctive features that suggest an important role in human immune defenses against intracellular pathogens. IL-12 can elicit production of IFN- $\gamma$ by PBMC (2).

Address correspondence to Dr. Peter F. Barnes, HMR 904, University of Southern California School of Medicine, Los Angeles, CA 90033.

Received for publication 27 May 1993 and in revised form 9 December 1993

1. Abbreviation used in this paper: NK, natural killer.

J. Clin. Invest.

(c) The American Society for Clinical Investigation, Inc.

0021-9738/94/04/1733/07 \$2.00

Volume 93, April 1994, 1733-1739
IL-12 is more potent than IL- 2 , IFN- $\gamma$, and IFN- $\alpha$ in enhancing NK cell-mediated cytotoxicity (2), augments antigen-dependent proliferation by $\mathrm{CD}^{+}$cytotoxic $\mathrm{T}$ lymphocytes $(5)$, and facilitates development of Th1 cells (6-9). Preliminary studies suggest that IL- 12 enhances cytotoxicity by $\mathrm{CD}^{+} \mathrm{T}$ cells against macrophages pulsed with Mycobacterium tuberculosis (10). Despite IL-12's multiple immunoregulatory effects in vitro, there is little published information on its role in modulating the immune response in vivo.

Tuberculous pleuritis provides an excellent model to study the immune response in vivo. Inflammatory cells and pleural fluid are readily obtained from the site of disease, and immunologic reactivity against $M$. tuberculosis is compartmentalized in the pleural space. In pleural fluid, there is selective concentration of antigen-reactive $T$ lymphocytes (11) and cytokines with antimycobacterial activity, such as IFN- $\gamma$ and TNF- $\alpha(12,13)$. To gain insight into the immunoregulatory potential of IL-12 in vivo, we evaluated IL-12 production in the pleural fluid of patients with tuberculous pleuritis.

\section{Methods}

Patient population. Pleural fluid and blood were obtained from 15 patients with tuberculous pleuritis seen at the Los Angeles County-University of Southern California Medical Center. All patients had unilateral exudative effusions without clinical evidence of concomitant pulmonary tuberculosis or HIV infection. The diagnosis was confirmed either by pathologic demonstration of granulomatous pleuritis on closed pleural biopsy ( 10 cases) or growth of $M$. tuberculosis from pleural fluid or tissue ( 9 cases). All patients responded to antituberculosis therapy. The experiments described were performed on 5-9 of these 15 patients.

Pleural fluid was also obtained from 9 patients with pleural effusions resulting from malignancies. Blood was obtained from 10 healthy tuberculin reactors, 4 healthy tuberculin-negative persons, and 9 patients with culture-proven pulmonary tuberculosis.

Isolation of RNA and CDNA synthesis. Freshly isolated pleural fluid mononuclear cells and PBMC from patients with tuberculous pleuritis were lysed with $4 \mathrm{M}$ guanidinium isothiocyanate and stored at $-20^{\circ} \mathrm{C}$ before preparation of RNA, which was isolated as previously described (14). cDNA was synthesized from RNA by priming $\sim 1 \mu \mathrm{g}$ of total RNA at $42^{\circ} \mathrm{C}$ for $1 \mathrm{~h}$ in a final volume of $20 \mu \mathrm{l}$ containing $1 \mu \mathrm{g}$ of an oligo-dT primer (Pharmacia Fine Chemicals, Piscataway, NJ), 200 nmol of each dNTP (Pharmacia), and M-MLV reverse transcriptase (Bethesda Research Laboratories, Gaithersburg, MD) at $200 \mathrm{U} / \mu \mathrm{g}$ RNA.

Amplification of $c D N A$ by PCR. Aliquots of $c D N A$ were amplified by PCR, using oligonucleotide primers specific for $\beta$-actin and the $\mathrm{p} 40$ and p35 chains of IL-12. A DNA thermocycler 480 (Perkin-Elmer Cetus, Norwalk, CT) ran 26 cycles of denaturation at $94^{\circ} \mathrm{C}$ for $1 \mathrm{~min}$ and annealing/extension at $65^{\circ} \mathrm{C}$ for $2 \mathrm{~min}$ in the case of $\beta$-actin, and 35 cycles of denaturation at $95^{\circ} \mathrm{C}$ for $1 \mathrm{~min}$ and annealing/extension at $60^{\circ} \mathrm{C}$ for $2 \mathrm{~min}$ in the case of $\mathrm{p} 40$ and $\mathrm{p} 35$. Primer sequences were: $(a)$ $\beta$-actin 5': GTGGGGCGCCCCAGGCACCA, 3': CTCCTTAATGTCACGCACGATTTC; $(b)$ p40 5': CCAAGAACTTGCAGCAGCTGA- 
AG, 3': TGGGTCTATTCCGTTGTGTC; (c) p35 5': CCTCAGTTTGGCCAGAAACC; 3': GGTCTTTCTGGAGGCCAGGC. PCR product was subjected to electrophoresis on $2 \%$ agarose gels and visualized by staining with ethidium bromide.

Hybridization of $P C R$ product. To confirm the specificity of amplification of p40 mRNA, PCR product was transferred to Hybond-N nylon membranes (Amersham Corp., Arlington Heights, IL) and hybridized with a radioactive oligonucleotide probe complementary to sequences internal to those recognized by the $\mathrm{p} 40$-specific primers. The sequence of the probe is: TGGCTGAGGTCTTGTCCGTGAAGACTCTAT. The probe was labeled at the $5^{\prime}$ end with T4 polynucleotide kinase (Boehringer Mannheim Biochemicals, Indianapolis, IN) and $\left[{ }^{32} \mathrm{P}\right] \gamma \mathrm{ATP}(7,000 \mathrm{Ci} / \mathrm{mM}, \mathrm{ICN}$, Costa Mesa, CA $)$. Blots were hybridized with probe for $4 \mathrm{~h}$, washed for $5 \mathrm{~min}$ with $2 \times$ SSC and $0.5 \%$ SDS, then exposed to $x$-ray film. Membranes were scanned with a radioanalytic imaging system (AMBIS, Automated Microbiology Systems Inc., San Diego, CA).

Validity of PCR amplification for semiquantitative comparison of IL-12 mRNA expression. A number of controls were employed to permit semiquantitative comparison of p40 mRNA expression in the pleural fluid and blood samples studied. Upon PCR amplification of serial fivefold dilutions of sample cDNAs, a concomitant decrease in PCR product was observed. Variation of the number of PCR cycles did not change the relative differences between samples. These studies indicate that our PCR conditions are not within the plateau phase of amplification. Each experiment included a positive control (cDNA from Staphylococcus aureus Cowan I strain-stimulated PBMC) and a negative control to which no cDNA was added. In addition, precautions were taken to avoid cross-contamination of samples, including assembling reactions in laminar flow hoods, use of aliquotted reagents, pipettes dedicated for assembling PCR reactions, and use of aerosol-resistant pipette tips (Continental Lab Products, La Jolla, CA).

Stimulation of mononuclear cells from patients with tuberculous pleuritis with heat-killed M. tuberculosis. $2 \times 10^{6}$ pleural fluid mononuclear cells or PBMC were obtained by centrifugation over Ficoll-Paque (Pharmacia) and suspended in 2-ml wells, each containing $10 \mu \mathrm{g} / \mathrm{ml}$ of heat-killed $M$. tuberculosis Erdman strain (15), 10\% human serum and RPMI (GIBCO, Grand Island, NY) with penicillin/streptomycin (GIBCO). Control wells contained no antigen. Cells were maintained at $37^{\circ} \mathrm{C}$ and $7.5 \% \mathrm{CO}_{2}$. Cell culture supernatants were harvested after $24 \mathrm{~h}$ and stored at $-70^{\circ} \mathrm{C}$.

Stimulation of adherent cells from pulmonary tuberculosis patients and healthy controls with heat-killed M. tuberculosis. PBMC were obtained from pulmonary tuberculosis patients, as well as from healthy tuberculin-positive and tuberculin-negative persons. Cells were suspended at $10^{7}$ cells $/ \mathrm{ml}$ in RPMI and $10 \%$ FCS (Hyclone Laboratories, Logan, UT), then incubated for $1 \mathrm{~h}$ at $37^{\circ} \mathrm{C}$ in petri dishes precoated with human serum. After washing with RPMI to remove nonadherent cells, the remaining cells were incubated with cold PBS without calcium or magnesium and incubated at $4^{\circ} \mathrm{C}$ for $20 \mathrm{~min}$. Adherent cells were removed with a rubber policeman and were $85-95 \%$ monocytes by Giemsa stain and by nonspecific esterase staining. Adherent cells were resuspended at $2 \times 10^{6}$ cells $/ \mathrm{ml}$ in $2 \mathrm{ml}$ wells containing $10 \mu \mathrm{g} / \mathrm{ml}$ of heat-killed $M$. tuberculosis Erdman, 10\% human serum, and RPMI. In order to facilitate measurement of IL-12 concentrations, neutralizing anti-human IL-4 antibodies (Genzyme Corp., Cambridge, MA) and anti-human IL-10 antibodies (Biosource International, Camarillo, CA) were added at $10 \mu \mathrm{g} / \mathrm{ml}$ to some wells. Control wells contained no antigen. Cell culture supernatants were harvested after $24 \mathrm{~h}$ and stored at $-70^{\circ} \mathrm{C}$.

Measurement of IL-12 and p40 concentrations. Concentrations of IL-12 and p40 were measured in pleural fluid, serum, and cell culture supernatants. Pleural fluid and blood were centrifuged at $2,500 \mathrm{rpm}$ for $10 \mathrm{~min}$, and supernatants from cell cultures were collected as outlined above.

IL-12 ELISAs. Rat monoclonal antibodies to human IL-12 were supplied by Dr. R. Chizzonite, Hoffmann-La Roche, Nutley, NJ. 4A1 is an $\mathrm{IgG}_{2 b}$ antibody and $4 D 6$ is an $\mathrm{IgG}_{1}$ antibody specific for $\mathrm{p} 40$ (16), whereas $20 \mathrm{C} 2$ antibody is an $\mathrm{IgG}_{1}$ antibody that reacts with a confor- mational epitope on the 75-kD IL-12 heterodimer and weakly with free p40 (17). ELISA plates (Nunc MaxiSorp, Thousand Oaks, CA) were coated with $100 \mu \mathrm{l} /$ well of purified $20 \mathrm{C} 2(5 \mu \mathrm{g} / \mathrm{ml})$ or $4 \mathrm{Al}(10 \mu \mathrm{g} / \mathrm{ml})$ at room temperature for $16 \mathrm{~h}$ and blocked with $1 \%$ BSA in PBS, $\mathrm{pH} 7.4$, for $1 \mathrm{~h}$ at $37^{\circ} \mathrm{C}$. Purified human rIL-12 and p40-containing supernatant fluid from a culture of COS cells transfected with IL-12 p40 cDNA alone (4) were used as standards. The amount of p40 in the COS-conditioned medium was determined by prior assay in the 4A1 ELISA using human rIL-12 as a standard, assuming that the anti-IL-12 antibodies $4 \mathrm{~A} 1$ and $4 \mathrm{D} 6$ reacted equally well with free p40 as with p40 in the IL-12 heterodimer. Serial dilutions of the standards and of the samples in Dulbecco's PBS with 5\% FCS were added to the plates and incubated for $3 \mathrm{~h}$ at room temperature with shaking. The plates were washed with distilled water, and $500 \mathrm{ng} / \mathrm{ml}$ of biotinylated 4D6 antibody was added to each well and incubated for $1 \mathrm{~h}$ at $37^{\circ} \mathrm{C}$. After another wash, $1 \mu \mathrm{g} / \mathrm{ml}$ of peroxidase-conjugated streptavidin (Sigma Chemical Co., St. Louis, MO) was added and incubated for $30 \mathrm{~min}$ at $37^{\circ} \mathrm{C}$. After washing, the plates were developed with $1 \mathrm{mM}$ ABTS/ $0.1 \%$ ( vol/ vol) $\mathrm{H}_{2} \mathrm{O}_{2}$ (Sigma Chemical Co.), and the absorbance at $405 \mathrm{~nm}$ was determined with a $V_{\max }$ Kinetic Microplate Reader (Molecular Devices, Palo Alto, CA). The sensitivity of the assays was 50-200 $\mathrm{pg} / \mathrm{ml}$. ELISAs using $4 \mathrm{Al}$ as the capture antibody detect heterodimeric IL-12 and free p40. ELISAs using $20 \mathrm{C} 2$ as the capture antibody are specific for heterodimeric IL-12 (Fig. 1). When pleural fluid and serum samples were tested on two separate occasions, the mean difference between duplicate measurements was $12.7 \pm 3.5 \%$ for the 4A1 ELISA and $14.3 \pm 5.1 \%$ for the $20 \mathrm{C} 2$ ELISA.

Antibody capture bioassay for $I L-12$. The antibody capture bioassay to detect IL-12 was performed as described (18) but modified to use Kit225/K6 indicator cells. Kit225/K6 cells, a cloned subline of the IL-2-dependent human T cell line Kit225 (provided by Dr. T. Waldmann, National Institutes of Health, Bethesda, MD), express IL-12 receptors and proliferate in response to IL-12 (19). Kit225/K6 cells were cultured in RPMI 1640 (BioWhittaker, Walkersville, MD) containing $10 \%$ FCS, $100 \mathrm{U} / \mathrm{ml}$ penicillin, $100 \mu \mathrm{g} / \mathrm{ml}$ streptomycin (GIBCO), $5 \times 10^{-5}$ M 2-mercaptoethanol (Fisher Scientific Co., Fair Lawn, NJ), and $100 \mathrm{U} / \mathrm{ml}$ human rlL-2 (provided by Dr. F. Khan, Hoffmann-La Roche). Serial dilutions of human rIL-12 standard or of samples were incubated in 4Al-coated ELISA plates for $3 \mathrm{~h}$ at room temperature as previously described (18). The plates were washed with distilled water and $2 \times 10^{5} \mathrm{Kit} 225 / \mathrm{K} 6$ cells were added in $100 \mu \mathrm{l}$ of RPMI 1640 supplemented with FCS, antibiotics, and 2-mercaptoethanol (as above) and $100 \mathrm{U} / \mathrm{ml}$ of IL-4 (Genzyme Corp.). IL-4 itself does not cause Kit225/K6 cells to proliferate but enhances their response to IL-12 (19). The cultures were incubated for $72 \mathrm{~h}$ at $37^{\circ} \mathrm{C}$, pulsed with $\left[{ }^{3} \mathrm{H}\right]$ thymidine, and harvested $6-8 \mathrm{~h}$ later. Concentrations of IL-12 were determined by comparison of proliferation induced by supernatants with that induced by serial dilutions of human rIL-12. When culture supernatants were tested on two separate occasions, the mean difference between duplicate measurements was $4.8 \pm 4.1 \%$.

Inhibition of proliferative responses to $M$. tuberculosis by anti-IL12 antibodies. Pleural fluid mononuclear cells $\left(10^{5}\right)$ were cultured in triplicate in $200-\mu$ l flat-bottomed wells containing $10 \%$ human serum, RPMI with penicillin/streptomycin, and $10 \mu \mathrm{g} / \mathrm{ml}$ of heat-killed $M$. tuberculosis Erdman or media alone. Proliferative responses were determined by measurement of $\left[{ }^{3} \mathrm{H}\right]$ thymidine incorporation after $6 \mathrm{~d}$ of culture as described (15). Inhibition of antigen-induced proliferation was assessed by measurement of $\left[{ }^{3} \mathrm{H}\right]$ thymidine incorporation in wells containing PBMC and $M$. tuberculosis, to which increasing concentrations of a 50:50 mixture of 4A1 and 20C2 anti-IL-12 antibodies had been added. Results were standardized by measurement of the percent inhibition, calculated as $100 \times[($ mean delta cpm for $M$. tuberculosis $)$ - (mean delta cpm for $M$. tuberculosis and anti-IL-12 antibodies)]/ mean delta $\mathrm{cpm}$ for $M$. tuberculosis. Controls were a 50:50 mix of purified rat $\operatorname{IgG}_{2 b}$ and a monoclonal $\operatorname{IgG}_{1}$ antibody to $\beta$-galactosidase.

Statistical analysis. For data that were normally distributed, the $t$ test was used to evaluate the statistical significance of results obtained. For data that were not normally distributed, the Wilcoxon rank-sum test was used. 

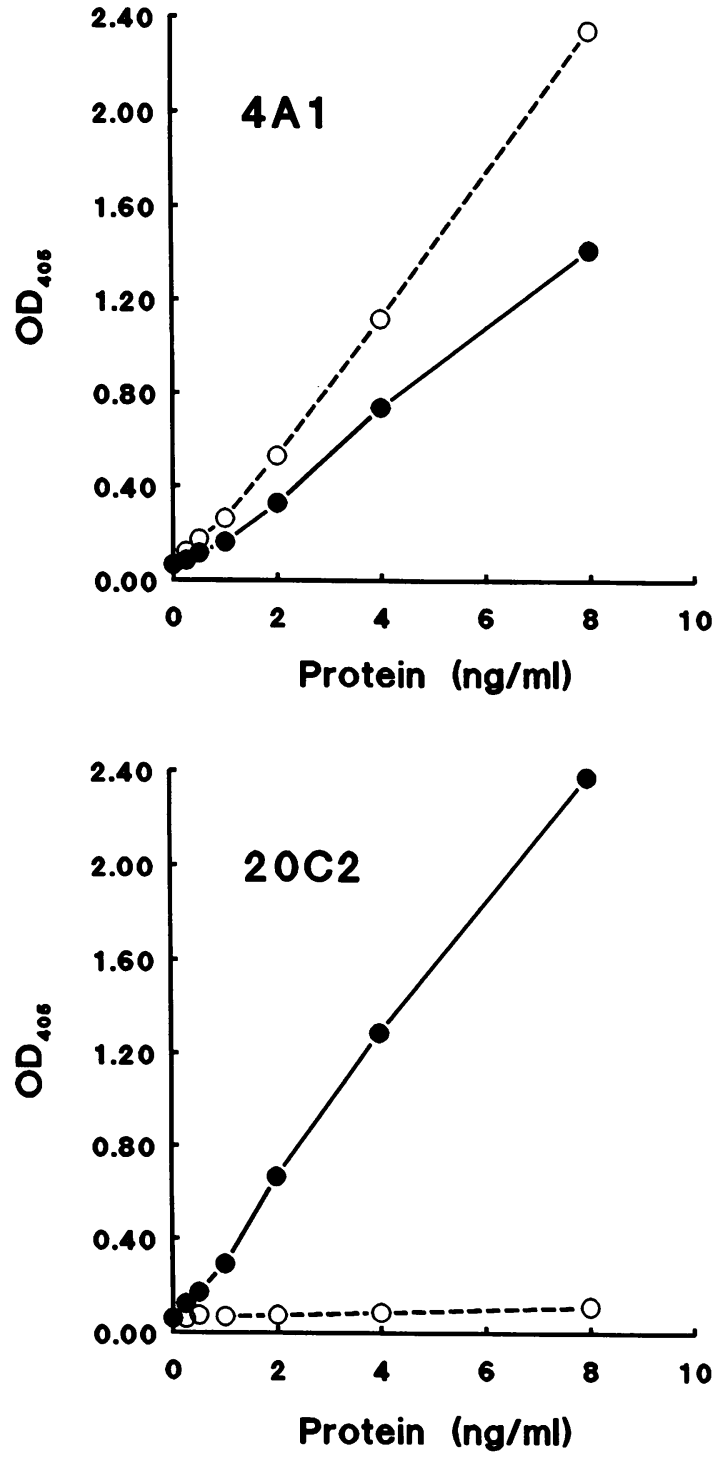

Figure 1. Specificity of IL-12 ELISAs. Twofold serial dilutions of purified human rIL-12 $(\bullet)$ or of conditioned medium from COS cells transfected with p40 cDNA clones $(O)$ were assayed in sandwich ELISAs using the anti-IL-12 antibodies 4A1 (top panel) or $20 \mathrm{C} 2$ (bottom panel) as the capture antibody. The 4A1 ELISA detected both heterodimeric IL-12 and free p40, whereas the 20C2 ELISA was essentially specific for heterodimeric IL-12.

\section{Results}

To evaluate the potential role of IL-12 in the local human immune response to mycobacterial infection, we sought to detect IL-12 mRNA and protein in pleural fluid and blood of

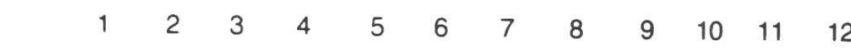

patients with tuberculous pleuritis. In addition, we evaluated IL-12 production in response to $M$. tuberculosis and the effect of anti-IL-12 antibodies on lymphocyte proliferation in response to $M$. tuberculosis.

$I L-12 \mathrm{mRNA}$ in pleural fluid mononuclear cells. We prepared RNA from freshly isolated pleural fluid mononuclear cells and PBMC from six patients with tuberculous pleuritis. RNA was reversed transcribed into cDNA and amplified by PCR with primers specific for the cDNAs of $\beta$-actin, and the p40 and p35 chains of IL-12. Ethidium bromide staining revealed PCR product for $\mathrm{p} 40 \mathrm{cDNA}$ in six of six pleural fluid samples and one of six PBMC samples (Fig. 2). PCR product for $\mathrm{p} 35 \mathrm{cDNA}$ was present in all pleural fluid and blood samples. Increased expression of $\mathrm{p} 40 \mathrm{mRNA}$ in pleural fluid compared to blood was not due to increased total mRNA in the pleural fluid samples, in as much as PCR product for $\beta$-actin cDNA was comparable in pleural fluid and blood (Fig. 2).

The specificity of PCR amplification of p 40 cDNA was confirmed by transfer of PCR product to nylon membranes and hybridization to an internal ${ }^{32} \mathrm{P}$-labeled probe. All pleural fluid samples incorporated radioactivity (mean 7,108 cpm), and weak radioactivity incorporation was noted in two of six PBMC samples (mean 898 cpm, Fig. 3).

IL-12 in pleural fluid. In order to determine whether selective mRNA expression for $\mathrm{p} 40$ in the pleural fluid reflected translation into protein, concentrations of p 40 and IL- 12 were measured in pleural fluid and serum of nine patients with tuberculous pleuritis. The ELISA with 4A1, which detects both heterodimeric IL-12 and free p40, revealed a mean pleural fluid concentration of $585 \pm 89 \mathrm{pg} / \mathrm{ml}$, which was significantly higher than the mean concentration in serum of the same patients ( $54 \pm 36 \mathrm{pg} / \mathrm{ml}, P=0.0003$, Fig. 4 ), or in pleural fluid of nine patients with malignancy $(123 \pm 35 \mathrm{pg} / \mathrm{ml}, P=0.0005$, Fig. 4). Using the ELISA with 20C2, which detects only heterodimeric IL-12, we found that the mean IL-12 concentration in pleural fluid was $165 \pm 28 \mathrm{pg} / \mathrm{ml}$, with undetectable levels in serum of the same patients $(P=0.0004$, Fig. 4$)$, or in pleural fluid of patients with malignancy $(P=0.0001$, Fig. 4). The difference between the results obtained with these two ELISAs indicates the presence of significant levels of free p40 in the pleural fluid of patients with tuberculous pleuritis, consistent with previous observations that free $\mathrm{p} 40$ is produced in excess by cell lines that make bioactive heterodimeric IL-12 $(3,4,17)$.

$I L-12$ produced by mononuclear cells in response to $M$. tuberculosis. In order to determine whether IL-12 was produced by pleural fluid cells in response to $M$. tuberculosis, we used the ELISA with $4 \mathrm{Al}$ to measure concentrations of free p 40 and heterodimeric IL-12 in supernatants of pleural fluid cells and PBMC of five patients, stimulated with heat-killed M. tuberculosis (Fig. 5, top). p40 and/or heterodimeric IL-12 were detectable in five of five pleural fluid supernatants (mean $825 \pm 351$ $\beta$-actin

IL-12 p40
Figure 2. Detection of mRNA for $\mathrm{p} 40$ by reversetranscription PCR. RNA from pleural fluid cells and PBMC was reverse transcribed into cDNA and amplified by PCR with primers specific for $\beta$-actin (top panel) and p40 (bottom panel). PCR product was visualized by staining with ethidium bromide. Lanes $1,3,5,7,9$, and 11 show results for PBMC; lanes 2, 4, 6, 8, 10, and 12 show results for pleural fluid cells. 


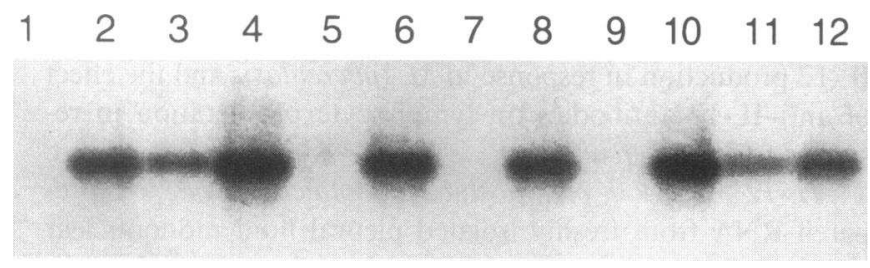

Figure 3. Hybridization of PCR product for p40 cDNA to radiolabeled probe. PCR product for $\mathrm{P} 40 \mathrm{cDNA}$ was transferred to nylon membranes and hybridized to an internal ${ }^{32} \mathrm{P}$-labeled probe. Lanes 1 , $3,5,7,9$, and 11 show results for PBMC; lanes $2,4,6,8,10$, and 12 show results for pleural fluid cells.

$\mathrm{pg} / \mathrm{ml}$ ), and in two of five PBMC supernatants (mean $347 \pm 306 \mathrm{pg} / \mathrm{ml}$ ). The ELISA with 20C2, specific for heterodimeric IL-12, showed detectable IL-12 in two of five pleural fluid supernatants and none of the PBMC supernatants (Fig. 5, middle). To confirm that the IL-12 detectable by ELISA was biologically active and to measure IL-12 concentrations lower than the limit of detection of the ELISAs, we used an antibody capture assay with IL-12-responsive Kit225/K6 cells. Bioactive IL-12 was detectable in five of five pleural fluid supernatants (mean $366 \pm 197 \mathrm{pg} / \mathrm{ml}$ ), and in one of five PBMC supernatants (Fig. 5, bottom). By means of these three assays, we found that no IL-12 or p40 was detectable in supernatants of pleural fluid cells or PBMC cultured in the absence of $M$. tuberculosis Erdman.

IL-12 production by adherent cells in response to $M$. tuberculosis. To assess the possible contribution of IL-12 to protective immunity against $M$. tuberculosis, we compared IL-12 production by 10 healthy tuberculin reactors with a protective immune response and by 9 pulmonary tuberculosis patients with ineffective immunity. When PBMC were stimulated with M. tuberculosis, IL-12 was not detectable in cell culture supernatants (data not shown). Because IL-12 is a growth factor for $T$ cells and NK cells, these cells may utilize IL-12 and prevent its detection. IL-12 is produced by monocytes but not by $T$ cells or NK cells (17). We therefore enriched for monocytes by obtaining adherent cells and stimulating them with $M$. tuberculosis. Adherent cells from healthy tuberculin reactors and from tuberculosis patients produced comparable concentrations of IL- 12 and p40, as determined by the 4A1 ELISA (mean of $361 \pm 116$ vs. $140 \pm 57 \mathrm{pg} / \mathrm{ml}$, respectively, $P=0.11$, Fig. 6 , top ). Concentrations of bioactive IL-12, measured by the antigen capture bioassay, were also comparable (mean of $24 \pm 10$ vs.

\section{Concentration (pg/ml)}

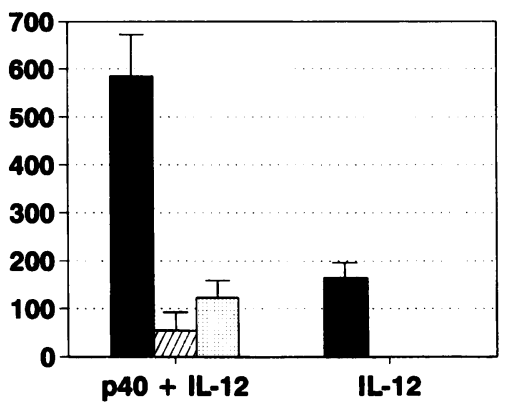

Figure 4. Concentrations of heterodimeric IL- 12 and p40 in pleural fluid and serum. The 4A1 ELISA, which detects both heterodimeric IL- 12 and $p 40$, and the $20 \mathrm{C} 2$ ELISA, which is specific for heterodimeric IL-12, were used to measure concentrations of IL-12 and p40 in pleural fluid (PF, solid bars) and serum of nine patients with tuberculous pleuritis (TB, cross-hatched bar) and nine patients with malignant pleural effusions (dotted bar).
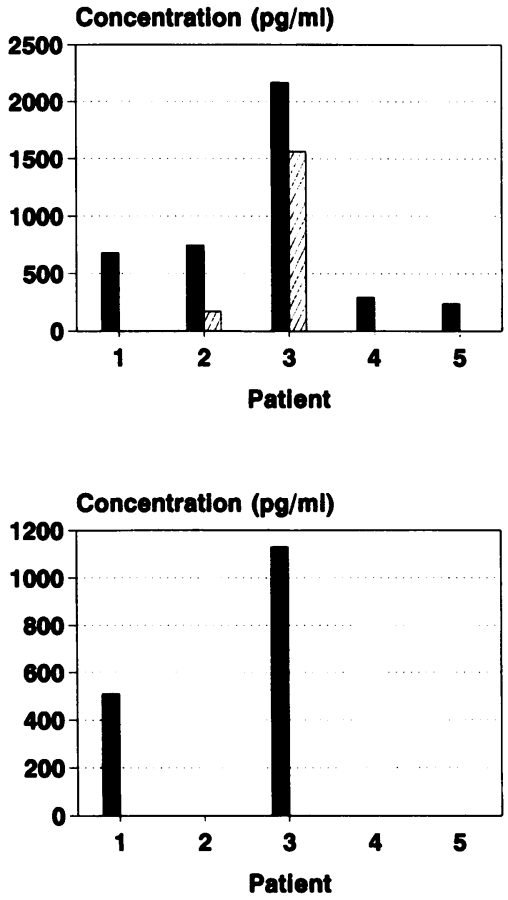

Figure 5. Concentrations of heterodimeric IL-12 and p40 in supernatants of cells cultured with $M$. tuberculosis. Pleural fluid cells ( solid bars) and PBMC (cross-hatched bars) from five patients were cultured with $M$. tuberculosis in vitro. IL-12 and $\mathrm{p} 40$ concentrations were determined in supernatants by $4 \mathrm{~A} 1$ ELISA (for p40 and heterodimeric IL-12; top panel), 20C2 ELISA (for heterodimeric IL12; middle panel), and antigen capture bioassay (for bioactive IL-12; bottom panel).

$6 \pm 6 \mathrm{pg} / \mathrm{ml}, P=0.14$, Fig. 6 , bottom). When adherent cells from four healthy tuberculin-negative donors were stimulated with $M$. tuberculosis, concentrations of IL- 12 and p 40 by $4 \mathrm{~A} 1$ ELISA were barely detectable (mean $39 \pm 18 \mathrm{pg} / \mathrm{ml}$ ) and heterodimeric IL-12 was not detectable by bioassay.

Because IL-4 and IL-10 inhibit IL-12 production (20, 21), we maximized our capacity to detect IL- 12 by adding anti-IL- 4 and anti-IL-10 antibodies to $M$. tuberculosis-stimulated cells. Under these conditions, the mean concentrations of IL-12 and p40 by $4 \mathrm{~A} 1$ ELISA were $2,781 \pm 724 \mathrm{pg} / \mathrm{ml}$ in healthy tuberculin reactors, vs. $3,430 \pm 1,656$ in tuberculosis patients $(P=0.74$, Fig. 6 , bottom). The concentrations of heterodimeric IL- 12 by bioassay were also similar ( $149 \pm 45$ vs. $154 \pm 82, P=0.96$, Fig. 6 , bottom). In four healthy tuberculin-negative persons, parallel experiments yielded mean concentrations of IL-12 and p40 of $200 \pm 112 \mathrm{pg} / \mathrm{ml}$, and undetectable concentrations of bioactive IL-12.

Effect of anti-IL-12 antibodies on $M$. tuberculosis-induced proliferation. Because IL-12 was present in pleural fluid and was produced upon stimulation with $M$. tuberculosis, we wished to determine if IL-12 contributed to lymphocyte proliferation in response to mycobacterial antigens. Pleural fluid mononuclear cells from six patients were stimulated with heatkilled $M$. tuberculosis in culture, and the effects of adding a 50:50 mix of the neutralizing anti-IL-12 monoclonal antibod- 
Conc. (pg/ml) (Thousands)
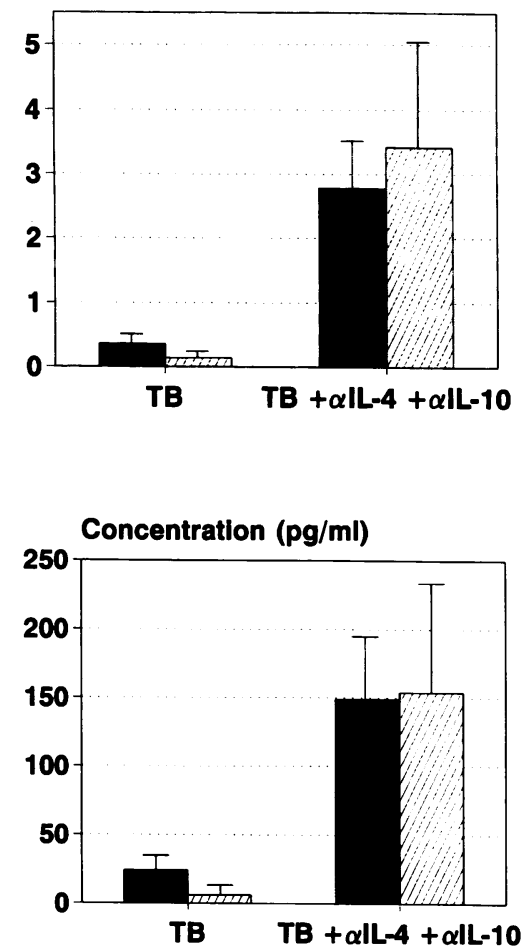

Figure 6. Concentrations of bioactive IL-12 and p40 in supernatants of adherent cells cultured with $M$. tuberculosis. Adherent cells were obtained from PBMC of 10 healthy tuberculin reactors (puripositive, solid bars) and 9 pulmonary tuberculosis ( TB, cross-hatched bars) patients and cultured with heat-killed $M$. tuberculosis Erdman $(T B)$ or M. tuberculosis Erdman, anti-IL-4 and anti-IL-10 $(T B+\alpha I L-4$ $+\alpha I L-10)$. IL-12 and p40 concentrations were determined in supernatants by 4A1 ELISA (for $\mathrm{p} 40$ and heterodimeric IL-12; top panel) and antigen capture bioassay (for bioactive IL-12; bottom panel). fied protein derivative

ies 4A1 and 20C2 were determined. Addition of anti-IL-12 antibodies at $5 \mu \mathrm{g} / \mathrm{ml}$ inhibited antigen-induced proliferation by a mean of $18 \pm 6 \%$, and addition of $20 \mu \mathrm{g} / \mathrm{ml}$ inhibited proliferation by a mean of $36 \pm 7 \%$ (Fig. 7). Addition of isotype control antibodies did not affect antigen-induced proliferation.

\section{Discussion}

The results presented in this report provide new evidence that IL-12 may contribute to the human immune response to infectious agents in vivo. In tuberculous pleuritis, IL-12 mRNA and protein were concentrated at the site of disease, IL-12 was produced by pleural fluid cells in response to $M$. tuberculosis, and anti-IL-12 antibodies suppressed $M$. tuberculosis-induced proliferation. These data, combined with the capacity of IL-12 to favor development of Th1 cells and enhance cytotoxic responses, suggest that IL-12 potentiates $\mathrm{T}$ cell responses in immune resistance to mycobacteria and other microbial pathogens.

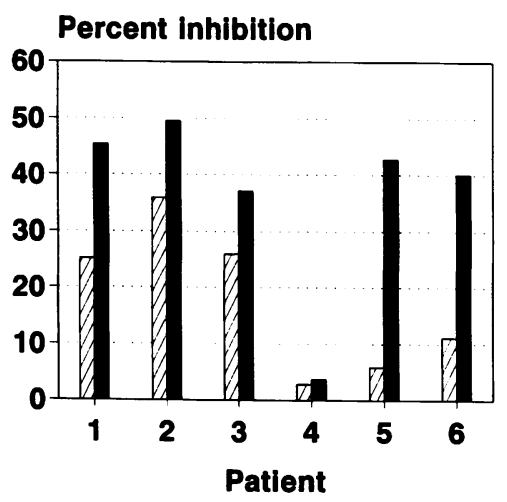

Figure 7. Inhibition of proliferative response to $M$. tuberculosis by anti-IL-12 antibodies. Pleural fluid mononuclear cells were cultured with media alone, heatkilled M. tuberculosis, or M. tuberculosis and anti-IL-12 antibodies at (cross-hatched bars) 5 or (solid bars) $20 \mu \mathrm{g}$ / ml. Results are shown as the percent inhibition of antigen-induced pro-

liferation. Mean radioactivity incorporation was $6,275 \mathrm{cpm}$ with media alone and 126,210 cpm with M. tuberculosis.
IL-1 2 consists of $\mathrm{p} 40$ and $\mathrm{p} 35$ chains, both of which are required for bioactivity (1). We found enhanced mRNA expression of $\mathrm{p} 40$ but not $\mathrm{p} 35$ in pleural fluid cells compared to PBMC. Heterodimeric IL- 12 and free p40 were present in tuberculous pleural effusions but not in malignant pleural effusions, suggesting that IL-12 is produced in the local immune response to infection. Our findings are consistent with previous observations that p40 mRNA and free p40 protein are produced by cells producing bioactive IL-12 $(3,4,10)$. Expression of p35 mRNA is often not associated with IL- 12 production (22), as was the case in PBMC in the current study.

IL-12 was produced by pleural fluid cells in response to $M$. tuberculosis, and anti-IL-12 antibodies inhibited M. tuberculosis-induced proliferation. These findings suggest that IL-12 contributes to lymphocyte recognition of $M$. tuberculosis antigens, probably through enhancing proliferation by activated $\mathrm{T}$ cells. IL-12 induces proliferation of activated human $\mathrm{T}$ cells, and can synergize with suboptimal amounts of IL-2 to enhance proliferation $(23,24)$. IL-12 may therefore serve as a growth factor during the early phase of $\mathrm{T}$ cell expansion in response to mycobacterial and other microbial antigens.

Because tuberculous pleuritis represents a resistant response to infection and commonly resolves without therapy (25), cytokines that are concentrated in the pleural space are likely to play a role in immune resistance. Concentrations of IFN- $\gamma$ and TNF- $\alpha$ are elevated in pleural fluid $(12,13)$, and both cytokines exhibit antimycobacterial effects. Although the capacity of IFN- $\gamma$ to enhance antimycobacterial activity of human macrophages remains controversial $(26,27)$, IFN- $\gamma$ reduces the bacillary burden in lepromatous leprosy patients (28) and is a functional marker of murine T cells that confer adoptive immunity against tuberculosis $(29,30)$. TNF- $\alpha$ augments the mycobactericidal capacity of human macrophages (31) and is essential for granuloma formation to contain murine mycobacterial infection (32). Our findings of elevated IL12 concentrations at the site of disease in tuberculous pleuritis suggest that IL-12 participates in a resistant immune response to $M$. tuberculosis. Although peripheral blood cells of healthy tuberculin reactors and pulmonary tuberculosis patients produced similar amounts of IL-12 in response to M. tuberculosis, this does not exclude an important role for IL- 12 in cell-mediated immunity. One possibility that remains to be examined is the production of IL-12 at the site of infection in patients with various clinical manifestations of tuberculous infection.

IL-12 may contribute to antimycobacterial defenses through several mechanisms. IL-12 in the pleural space may trigger production of IFN- $\gamma$ by local NK cells and/or T cells. Because IFN- $\gamma$ enhances TNF- $\alpha$ production by monocytes in response to mycobacteria (33), and TNF induces IFN- $\gamma$ production by NK cells ( 34 ), these cytokines may comprise a positive feedback cycle that yields high local cytokine concentrations, facilitating granuloma formation and bacillary elimination (13).

Another potential means by which IL-12 could facilitate mycobacterial clearance is through favoring development of Th1 cells which are thought to mediate resistance against mycobacteria $(35,36)$. IL-12 induces differentiation of human and murine Th1-like cells $(6,37)$ and can cure murine leishmaniasis through enhanced production of $\operatorname{IFN}-\gamma(7,38)$. In tuberculous pleuritis, Th 1 cytokines predominate over Th 2 cytokines in pleural fluid (39), perhaps reflecting the effects of IL-12. It is intriguing to speculate that macrophages at the site of disease ingest mycobacteria and produce IL-12, which in 
turn favors differentiation of precursor $T$ cells into $T h 1$ cells $(8$, $9,40)$. This effect may be mediated either directly by IL-12 or through stimulation of IFN- $\gamma$ production by NK cells and/or T cells.

IL-12 may also enhance antimycobacterial immune defenses through its effects on cytolytic cells, which are thought to contribute to human immune defenses against $M$. tuberculosis (41). Mycobacterium tuberculosis induces antigen-specific cytotoxic $\mathrm{CD}^{+} \mathrm{T}$ cells $(42)$ and NK cells enhance mycobactericidal activity of macrophages in vitro (43). In addition, antigen-specific cytolytic $\mathrm{CD}^{+} \mathrm{T}$ cells and NK cells have been found at the site of disease in tuberculosis patients $(44,45)$. Because IL-12 enhances cytotoxicity and augments proliferation by antigen-specific T cells and NK cells $(5,46,47)$, IL-1 2 may facilitate antigen-specific and nonspecific cytolytic immune defenses against intracellular pathogens, including $M$. tuberculosis. An intriguing property of IL-12 is its capacity to induce proliferation by cytolytic $\mathrm{T}$ cells only upon costimulation of the $T$ cell receptor with antigen or anti-CD3 (5). In contrast, cytokines such as IL-2 and IL-7 cause proliferation in the absence or presence of antigen (48). IL-12 may thus be a candidate to control the cytolytic arm of the initial immune response to microbial pathogens by inducing expansion of cytolytic $\mathrm{T}$ cells only when antigen is encountered.

In summary, IL-12 has the potential to contribute to immune defenses against $M$. tuberculosis and other intracellular pathogens by enhancing production of IFN- $\gamma$, facilitating development of Th 1 cells and orchestrating antigen-specific and nonspecific cytolytic mechanisms. Further investigations should clarify the functional role of IL-12 in vivo and its potential as an immunostimulatory agent in selected patients with tuberculosis and other infectious diseases.

\section{Acknowledgments}

We thank Dr. Patrick Brennan for provision of M. tuberculosis Erdman, and we thank Drs. Ahmed Badr, Mark Lindsay, David Chao, Anooshirvan Hami, Vinod Ambastha and Jonathan Leung for their assistance in obtaining pleural fluid samples.

This work was supported by the UNDP/World Bank/World Health Organization Special Programme for Vaccine Development (IMMTUB), the Heiser Program for Research in Leprosy and Tuberculosis, and the National Institutes of Health (AI-27285). Computational assistance was provided by the CLINFO project, funded by the National Institutes of Health (RR-00043). Mycobacterial products were provided through contract AI-05074 from the National Institute of Allergy and Infectious Diseases.

\section{References}

1. Wolf, S. F., P. A. Temple, M. Kobayashi, D. Young, M. Dicig, J. Lowe, R. Dzialo, L. Fitz, C. Ferenz, L. Azzoni, et al. 1991. Cloning of cDNA for natura killer cell stimulatory factor, a heterodimeric cytokine with multiple biologic effects on T and natural killer cells. J. Immunol. 146:3074-3081.

2. Kobayashi, M., L. Fitz, M. Ryan, R. M. Hewick, S. C. Clark, S. Chan, R. Loudon, F. Sherman, B. Perussia, and G. Trinchieri. 1989. Identification and purification of natural killer cell stimulatory factor (NKSF), cytokine with multiple biologic effects on human lymphocytes. J. Exp. Med. 170:827-845.

3. Stern, A. S., F. J. Podlaski, J. D. Hulmes, Y. E. Pan, P. M. Quinn, A. G. Wolitzky, P. C. Familletti, D. L. Stremlo, T. Truitt, R. Chizzonite, et al. 1990. Purification to homogeneity and partial characterization of cytotoxic lymphocyte maturation factor from human B-lymphoblastoid cells. Proc. Natl. Acad. Aci. USA. 87:6808-6812.

4. Gubler, U., A. O. Chua, D. S. Schoenhaut, C. M. Dwyer, W. McComas, R. Motyka, N. Nabavi, A. G. Wolitzky, P. M. Quinn, P. C. Familletti, et al. 1991. Coexpression of two distinct genes is required to generate secreted bioactive cytotoxic lymphocyte maturation factor. Proc. Natl. Acad. Aci. USA. 88:4143-4147.
5. Bertagnolli, M. M., B.-Y. Lin, D. Young, and S. H. Herrmann. 1992. IL-12 augments antigen-dependent proliferation of activated T lymphocytes. J. Immunol. 149:3778-3783.

6. Manetti, R., P. Parronchi, M. G. Giudizi, M. P. Piccinni, E. Maggi, G. Trinchieri, and S. Romagnani. 1993. Natural killer cell stimulatory factor (interleukin 12 [IL-12]) induces T helper type 1 (Th1)-specific immune responses and inhibits the development of IL-4-producing Th cells. J. Exp. Med. 177:11991204.

7. Sypek, J. P., C. L. Chung, S. E. H. Mayor, J. M. Subramanyam, S. J. Goldman, D. S. Sieburth, S. F. Wolf, and R. G. Schaub. 1993. Resolution of cutaneous leishmaniasis: interleukin 12 initiates a protective $\mathrm{T}$ helper type 1 immune response. J. Exp. Med. 177:1797-1802.

8. Locksley, R. M. 1993. Interleukin 12 in host defense against microbial pathogens. Proc. Natl. Acad. Sci. USA. 90:5879-5880.

9. Trinchieri, G. 1993. Interleukin-12 and its role in the generation of Th1 cells. Immunol. Today 14:335-337.

10. Boom, W. H., Z. Toossi, S. F. Wolf, and K. A. Chervenak. 1992. The modulation by IL-2, NKSF (IL-12/CLMF) and TGF- $\beta$ of CD $4^{+}$T-cell-mediated cytotoxicity for macrophages. In Proceedings of the 27th Joint Conference on Tuberculosis and Leprosy. U. S. Department of Health and Human Services, Washington, DC. 163-167.(Abstr.)

11. Fujiwara, H., and I. Tsuyuguchi. 1986. Frequency of tuberculin-reactive T-lymphocytes in pleural fluid and blood from patients with tuberculous pleurisy. Chest. 89:530-532.

12. Barnes, P. F., S. D. Mistry, C. L. Cooper, C. Pirmez, T. H. Rea, and R. L. Modlin. 1989. Compartmentalization of a CD4+ T lymphocyte subpopulation in tuberculous pleuritis. J. Immunol. 142:1114-1119.

13. Barnes, P. F., S.-J. Fong, P. J. Brennan, P. E. Twomey, A. Mazumder, and R. L. Modlin. 1990. Local production of tumor necrosis factor and interferon- $\gamma$ in tuberculous pleuritis. J. Immunol. 145:149-154.

14. Barnes, P. F., D. Chatterjee, J. S. Abrams, S. Lu, E. Wang, M. Yamamura, P. J. Brennan, and R. L. Modlin. 1992. Cytokine production induced by Mycobacterium tuberculosis lipoarabinomannan: Relationship to chemical structure. J. Immunol. 149:541-547.

15. Barnes, P. F., V. Mehra, G. R. Hirschfield, S.-J. Fong, C. Abou-Zeid, G. A. W. Rook, S. W. Hunter, P. J. Brennan, and R. L. Modlin. 1989. Characterization of T-cell antigens associated with the cell wall protein-peptidoglycan complex of Mycobacterium tuberculosis. J. Immunol. 143:2656-2662.

16. Chizzonite, R., T. Truitt, F. J. Podlaski, A. G. Wolitzky, P. M. Quinn, P. Nunes, A. S. Stern, and M. K. Gately. 1990. IL-12: monoclonal antibodies specific for the $40 \mathrm{kDa}$ subunit. J. Immunol. 147:1548-1556.

17. D'Andrea, A., M. Rengaraju, N. M. Valiante, J. Chehimi, M. Kubin, M. Aste, S. H. Chan, M. Kobayashi, D. Young, E. Nickbarg, et al. 1992. Production of natural killer cell stimulatory factor (interleukin 12) by peripheral blood mononuclear cells. J. Exp. Med. 176:1387-1398.

18. Gately, M. K., and R. Chizzonite. 1992. Measurement of human and mouse interleukin 12. In Current Protocols in Immunology, Volume 1. J. E. Coligan, A. M. Kruisbeek, D. H. Margulies, E. M. Shevach, and W. Strober, editors. Greene Publishing Associates and Wiley-Interscience, New York. 6.16.1-6.16.8.

19. Desai, B. B., T. Truitt, S. Honasoge, R. Warrier, R. Chizzonite, and M. K. Gately. 1993. Expression of functional IL-12R on a human IL-2-dependent T cell line. J. Immunol. 150:207A.

20. D'Andrea, A., M. Aste-Amezaga, N. M. Valiante, X. Ma, M. Kubin, and G. Trinchieri. 1993. Interleukin 10 (IL-10) inhibits human lymphocyte interferon- $\gamma$ production by suppressing natural killer cell stimulatory factor/IL-12 synthesis in accessory cells. J. Exp. Med. 178:1041-1048.

21. Tripp, C. S., S. F. Wolf, and E. R. Unanue. 1993. Interleukin 12 and tumor necrosis factor $\alpha$ are costimulators of interferon $\gamma$ production by natural killer cells in severe combined immunodeficiency mice with listeriosis, and interleukin 10 is a physiologic antagonist. Proc. Natl. Acad. Sci. USA. 90:3725-3729.

22. Wolf, S., D. Seiburth, B. Perussia, J. Yetz-Adalpe, and A. D'Andrea. 1992. Cell sources of natural killer stimulatory factor (NKSF/IL-12) transcripts and subunit expression. FASEB J. 6:A1335.(Abstr.)

23. Gately, M. K., B. B. Desai, A. G. Wolitsky, P. M. Quinn, C. M. Dwyer, F. J. Podlaski, P. C. Familletti, F. Sinigaglia, R. Chizonnite, U. Gubler, and A. S. Stern. 1991. Regulation of human lymphocyte proliferation by a heterodimeric cytokine, IL-12 (cytotoxic lymphocyte maturation factor). J. Immunol. 147:874-882.

24. Perussia, B., S. H. Chan, A. D'andrea, K. Tsuji, D. Santoli, M. Pospisil, D. Young, S. F. Wolf, and G. Trinchieri. 1992. Natural killer (NK) cell stimulatory factor or IL-1 2 has differential effects on the proliferation of TCR- $\alpha \beta+$, TCR- $\gamma \delta+$ T lymphocytes, and NK cells. J. Immunol. 149:3495-3502.

25. Roper, W. H., and J. J. Waring. 1955. Primary serofibrinous pleural effusion in military personnel. Am. Rev. Tuberc. 71:616-634.

26. Douvas, G. S., D. L. Looker, A. E. Vatter, and A. J. Crowle. 1985. Gamma interferon activates human macrophages to become tumoricidal and leishmanicidal but enhances replication of macrophage-associated mycobacteria. Infect. Immun. 50:1-8.

27. Shiratsuchi, H., J. L. Johnson, H. Toba, and J. J. Ellner. 1990. Strain- and 
donor-related differences in the interaction of Mycobacterium avium with human monocytes and its modulation by interferon- $\gamma$. J. Infect. Dis. 162:932-938.

28. Nathan, C. F., G. Kaplan, W. R. Levis, A. Nusrat, M. D. Witmer, S. A Sherwin, C. K. Job, C. R. Horowitz, R. M. Steinman, and Z. A. Cohn. 1986 Local and systemic effects of intradermal recombinant interferon- $\gamma$ in patients with lepromatous leprosy. $N$. Engl. J. Med. 315:6-15.

29. Kawamura, I., H. Tsukada, H. Yoshikawa, M. Fujita, K. Nomoto, and M. Mitsuyama. 1992. IFN- $\gamma$-producing ability as a possible marker for the protective T cells against Mycobacterium bovis BCG in mice. J. Immunol. 148:2887-2893.

30. Orme, I. M., E. S. Miller, A. D. Roberts, S. K. Furney, J. P. Griffin, K. M. Dobos, D. Chi, B. Rivoire, and P. J. Brennan. 1992. T lymphocytes mediating protection and cellular cytolysis during the course of Mycobacterium tuberculosis infection. J. Immunol. 148:189-196.

31. Bermudez, L. E. M., and L. S. Young. 1988. Tumor necrosis factor, alone or in combination with IL-2, but not IFN- $\gamma$, is associated with macrophage killing of Mycobacterium avium complex. J. Immunol. 140:3006-3013.

32. Kindler, V., A.-P. Sappino, G. E. Grau, P.-F. Piguet, and P. Vassalli. 1989 The inducing role of tumor necrosis factor in the development of bactericidal granulomas during BCG infection. Cell. 56:731-740.

33. Sampaio, E. P., A. L. Moreira, E. N. Sarno, A. M. Malta, and G. Kaplan 1992. Prolonged treatment with recombinant interferon $\gamma$ induces erythema nodosum leprosum in lepromatous leprosy patients. J. Exp. Med. 175:1729-1737.

34. Bancroft, G. J., K. C. Sheehan, R. D. Schreiber, and E. R. Unanue. 1989. Tumor necrosis factor is involved in the T cell-independent pathway of macrophage activation in scid mice. J. Immunol. 143:127-130.

35. Yamamura, M., K. Uyemura, R. J. Deans, K. Weinberg, T. H. Rea, B. R. Bloom, and R. L. Modlin. 1991. Defining protective responses to pathogens: cytokine profiles in leprosy lesions. Science (Wash. DC). 254:277-279.

36. Huygen, K., D. Abramowicz, P. Vandenbussche, F. Jacobs, J. DeBruyn, A. Kentos, A. Drowart, J. P. VanVooren, and M. Goldman. 1992. Spleen cell cytokine secretion in Mycobacterium bovis BCG-infected mice. Infect. Immun 60:2880-2886

37. Hsieh, C.-S., S. E. Macatonia, C. S. Tripp, S. F. Wolf, A. O'Garra, and K. M. Murphy. 1993. Development of $\mathrm{T}_{\mathrm{H}} 1 \mathrm{CD}^{+} \mathrm{T}$ cells through IL-12 produced by Listeria-induced macrophages. Science (Wash. DC). 260:547-549.
38. Heinzel, F. P., D. S. Schoenhaut, M. Rerko, L. E. Rosser, and M. K Gately. 1993. Recombinant interleukin 12 cures mice infected with Leishmania major. J. Exp. Med. 177:1505-1509.

39. Barnes, P. F., S. Lu, J. S. Abrams, E. Wang, M. Yamamura, and R. L. Modlin. 1993. Cytokine production at the site of disease in human tuberculosis. Infect. Immun. 61:3482-3489.

40. Romagnani, S. 1992. Induction of Th1 and Th2 responses: a key role for the 'natural' immune response. Immunol. Today. 13:379-381.

41. Kaufmann, S. H. E. 1988. CD8 ${ }^{+}$T lymphocytes in intracellular microbial infections. Immunol. Today. 9:168-174.

42. Ottenhoff, T. H. M., B. Kale Ab, J. D. A. van Embden, J. E. R. Thole, and R. Kiessling. 1988. The recombinant 65-kD heat shock protein of Mycobacterium bovis bacillus Calmette-Guerin/M. tuberculosis is a target molecule for $\mathrm{CD}^{+}$cytotoxic $\mathrm{T}$ lymphocytes that lyse human monocytes. J. Exp. Med. 168:1947-1954

43. Bermudez, L. E. M., and L. S. Young. 1991. Natural killer cell-dependent mycobacteriostatic and mycobactericidal activity in human macrophages. $\mathrm{J}$. Im munol. 146:265-270.

44. Lorgat, F., M. M. Keraan, P. T. Lukey, and S. R. Ress. 1992. Evidence for in vivo generation of cytotoxic T cells. PPD-stimulated lymphocytes from tuberculous pleural effusions demonstrate enhanced cytotoxicity with accelerated kinetics of induction. Am. Rev. Respir. Dis. 145:418-423.

45. Ota, T., Y. Okubo, and M. Sekiguchi. 1990. Analysis of immunologic mechanisms of high natural killer cell activity in tuberculous pleural effusions. Am. Rev. Respir. Dis. 142:29-33.

46. Robertson, M. J., R. J. Soiffer, S. F. Wolf, T. J. Manley, C. Donahue, D. Young, S. H. Herrmann, and J. Ritz. 1992. Response of human natural killer cells to NK cell stimulatory factor(NKSF): Cytolytic activity and proliferation of NK cells are differentially regulated by NKSF. J. Exp. Med. 175:779-788.

47. Gately, M. K., A. G. Wolitzky, P. M. Quinn, and R. Chizzonite. 1992. Regulation of human cytolytic lymphocyte responses by interleukin-12. Cell. Immunol. 143:127-142.

48. Bertagnolli, M., and S. Herrmann. 1990. IL-7 supports the generation of cytotoxic T lymphocytes from thymocytes. Multiple lymphokines required for proliferation and cytotoxicity. J. Immunol. 145:1706-1712. 